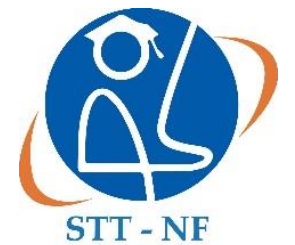

STT - NF
Jurnal Teknologi Terpadu Journal of Integrated Technology

https://journal.nurulfikri.ac.id/index.php/JTT ISSN : 2477-0043 ISSN ONLINE : 2460-7908

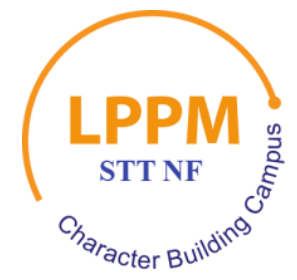

\title{
IMPLEMENTASI METODE HYBRID FUZZY C-MEANS DAN FUZZY SWARM UNTUK PENGELOMPOKKAN DATA BENANG PERUSAHAAN TEKSTIL
}

\author{
Tifanny Nabarian ${ }^{1}$, Muhammad Aris Ganiardi², Reza Firsandaya Malik ${ }^{3}$ \\ ${ }^{1}$ Teknik Informatika, Sekolah Tinggi Teknologi Terpadu Nurul Fikri \\ ${ }^{2}$ Manajemen Informatika, Politeknik Negeri Sriwijaya \\ ${ }^{3}$ Sistem Komputer, Universitas Sriwijaya \\ Jakarta Selatan, DKI Jakarta, Indonesia \\ tifany.nabarian@dosen.nurulfikri.ac.id, marisg2010@gmail.com, rezafm@unsri.ac.id
}

\begin{abstract}
Thread is the main raw materials for production process in textile companies. The availability of thread consumption data in textile companies can be used to determine the pattern of thread consumption in a certain period. Data clustering is one of method that can be used to form patterns for the data thread. In this research, hybrid Fuzzy C-Means (FCM) and Fuzzy Particle Swarm Optimization (FPSO) clustering algorithms are used, which are the combination of algorithms FCM and FPSO. This hybrid algorithm is able to overcome the weaknesses of the original algorithm, namely FCM. The purpose of this research is to implement the FCM-FPSO hybrid algorithm into an application, then test the performance. The application implemented Unified Process for software engineering method. In this application, the performance of three methods was compared, those methods are FCM, FPSO and Hybrid FCM-FPSO. The result of the implementation is the lowest average objective function is 3441.00 achieved by the Hybrid FCM-FPSO algorithm, then followed by the FCM algorithm with value of 3540.33 and the highest is achieved by the FPSO algorithm with value of 4485.40 . This result showed that the application was successfully proved that the FCM-FPSO Hybrid algorithm can produce the best thread clusters.
\end{abstract}

Keywords: fuzzy, swarm; thread; hybrid FCM-FPSO; clustering; unified process

\begin{abstract}
Abstrak
Salah satu bahan baku utama dalam proses produksi di perusahaan tekstil adalah benang. Ketersediaan data konsumsi benang pada perusahaan tekstil dapat dimanfaatkan untuk mengetahui pola konsumsi benang pada periode tertentu. Data mining metode clustering adalah salah satu teknik yang dapat digunakan untuk membentuk pola dari data benang tersebut. Pada penelitian ini, digunakan algoritma clustering Hibrid Fuzzy C-Means (FCM) dan Fuzzy Particle Swarm Optimization (FPSO), yaitu algoritma kombinasi dari FCM dan FPSO. Algoritma hibrida ini mampu mengatasi kelemahan dari algoritma asalnya, yaitu FCM. Tujuan dari penelitian ini yaitu menguji performa dari metode hibrid FCM-FPSO dengan cara mengimplementasikan pengelompokan data benang perusahaan tekstil ke dalam sebuah aplikasi. Aplikasi dikembangkan dengan menerapkan model Unified Process (UP). Hasil dari implementasi tersebut adalah nilai rata-rata fungsi objektif terendah dicapai oleh algoritma hibrid FCM-FPSO sebesar 3441,00 kemudian diikuti oleh algoritma FCM dengan nilai sebesar 3540,33 dan yang tertinggi dicapai oleh algoritma FPSO dengan nilai sebesar 4485,40. Nilai rata-rata fungsi objektif yang terendah ini menunjukkan bahwa aplikasi yang dibangun berhasil membuktikan keunggulan algoritma hybrid FCM-FPSO dalam menghasilkan cluster data benang.
\end{abstract}

Kata kunci: fuzzy, swarm; benang; hibrid FCM-FPSO; clustering; unified process 


\section{PENDAHULUAN}

Pada Persaingan di dunia industri mengharuskan pihak manajemen perusahaan untuk selalu memikirkan strategi terbaik sehingga proses produksi dapat terus berlangsung. Kebutuhan akan data dan informasi menjadi sesuatu yang diutamakan dalam dunia industri. Melimpahnya ketersediaan data industri merupakan aset strategis yang dimiliki oleh setiap perusahaan [1]. Oleh karena itu, dibutuhkan suatu teknik khusus agar data industri yang tersedia dapat dimanfaatkan untuk pengaturan strategi bisnis. Data mining merupakan salah satu teknik ilmiah yang dapat dimanfaatkan oleh perusahaan untuk mencapai tujuan tersebut. Terdapat beragam metode dalam teknik data mining, clustering adalah salah satunya. Tujuan dari metode clustering ini yaitu untuk dapat melihat pola karakteristik yang terbentuk dari setiap data sehingga akan memudahkan dalam pengaturan strategi perusahaan. Metode clustering yang diimplementasikan pada penelitian ini adalah metode hibrida antara algoritma Fuzzy C-Means dan Fuzzy Particle Swarm Optimization. Pada penelitian ini, data yang akan dianalisis adalah data konsumsi benang pada salah satu perusahaan tekstil di kota Batam. Data benang dipilih karena merupakan salah satu bahan baku utama pada proses produksi di perusahaan tekstil tersebut sehingga hasil clustering dapat bermanfaat secara signifikan untuk strategi perusahaan.

Beberapa penelitian di bidang bisnis telah mengimplementasikan teknik data mining metode fuzzy clustering, diantaranya untuk memecahkan permasalahan di koperasi simpan pinjam [2], transaksi swalayan [3], sampai penjualan makanan pada bisnis restoran [4]. Pada penelitian ini dilakukan analisis terhadap data benang pada perusahaan tekstil dengan membangun aplikasi pengelompokkan data benang menggunakan metode unified process. Selain itu, juga dilakukan perbandingan performa diantara tiga algoritma, diantaranya Fuzzy C-Means, Fuzzy Particle Swarm Optimization, serta hibrida dari kedua algoritma tersebut.

\section{TINJAUAN PUSTAKA}

Pada bagian ini dapat dijelaskan landasan teori yang dibahas yang bersifat khusus, penelitian terkait yang menjadi dasar penelitian, hipotesis penelitian (jika ada), dan model penelitian.

\subsection{Data mining dan Fuzzy Clustering}

Data mining adalah proses berulang di mana setiap proses kemajuannya didefinisikan sebagai penemuan, baik melalui metode manual maupun otomatis. Data mining berguna untuk analisis eksplorasi, yaitu di saat belum ada gagasan yang telah ditentukan sebelumnya dan belum diketahui hasil yang ingin didapatkan. Data mining merupakan teknik pencarian informasi baru, berharga, dan nontrivial dalam volume data yang besar. Hasil terbaik bisa dicapai dengan menyelaraskan pengetahuan pakar (manusia) dalam menggambarkan tujuan dan masalah dengan kemampuan pencarian pada komputer.

Metode data mining yang diimplementasikan pada penelitian ini adalah metode clustering. Clustering adalah teknik pengelompokan yang tidak membutuhkan fase pelatihan atau pembelajaran dalam pemanfaatannya (unsupervised). Tujuan dari metode clustering adalah mengelompokkan sejumlah data atau objek ke dalam cluster (himpunan bagian, kelompok, atau kelas) [5]. Pengelompokan harus memiliki nilai kemiripan (homogeneity) antar objek di dalam suatu cluster dan ketidakmiripan (heterogeneity) antar objek pada cluster yang berbeda. Konsep jarak dapat diartikan sebagai konsep ketidakmiripan. Apabila jarak dua data atau objek titik cukup dekat, maka dua objek itu dapat dikatakan mirip. Semakin jauh jarak, maka semakin tinggi juga nilai ketidakmiripannya [6]. Metode clustering secara umum diklasifikasikan menjadi dua, yaitu hard clustering dan soft (fuzzy) clustering. Metode hard clustering menetapkan setiap objek ke grup tunggal, sementara metode fuzzy clustering memperkenalkan derajat keanggotaan antara objek dan grup yang berbeda dari dataset [5].

\subsection{Fuzzy C-Means (FCM)}

Metode FCM diajukan oleh James C. Bezdek pada tahun 1981. Pada metode FCM setiap data dapat menjadi anggota pada lebih dari satu cluster. FCM membagi himpunan sejumlah $\mathrm{n}$ objek $\mathrm{o}=$ $\{01,02, \ldots$, on $\}$ pada dimensi Rd ke dalam c $(1<\mathrm{c}<$ n ) cluster fuzzy dengan $Z=\{z 1, z 2, \ldots, z c\}$ sebagai pusat cluster atau centroid. Fuzzy clustering dari sejumlah objek dideskripsikan dengan matriks fuzzy $\mu$ dengan $\mathrm{n}$ jumlah baris dan $\mathrm{c}$ jumlah kolom, untuk $\mathrm{n}$ merupakan jumlah dari objek data dan c jumlah dari cluster. Elemen baris ke-i dan kolom ke-j pada $\mu, \mu \_\mathrm{ij}$, mengindikasikan derajat keanggotaan dari objek ke-i terhadap kolom ke-j [7]. Algoritma dari FCM adalah sebagai berikut [7].

1. Tentukan nilai $m(m>1)$; inisialisasi nilai derajat keanggotaan $\mu_{i j}, i=1,2, \ldots, n ; j=$ $1,2, \ldots, c$.

2. Hitung pusat cluster $z_{j}, j=1,2, \ldots, c$ menggunakan Persamaan (1).

$$
z_{j}=\frac{\sum_{i=1}^{n} \mu_{i j}^{m} o_{i}}{\sum_{i=1}^{n} \mu_{i j}^{m}}
$$

3. Hitung jarak Euclidean $d_{i j}, i=1,2, \ldots, n ; j=$ $1,2, \ldots, c$

4. Perbarui nilai derajat keanggotaan $\mu_{i j}, i=$ $1,2, \ldots, n ; j=1,2, \ldots, c$ menggunakan Persamaan (2). 


$$
\mu_{i j}=\frac{1}{\sum_{k=1}^{c}\left(\frac{d_{i j}}{d_{i k}}\right)^{\frac{2}{m-1}}}
$$

5. Jika nilai fungsi objektif berkurang, dilanjutkan kembali ke langkah 2, jika tidak maka algoritma dihentikan.

\subsection{Fuzzy Particle Swarm Optimization (FPSO)}

Algoritma particle swarm optimization adalah algoritma komputasi evolusioner yang diusulkan oleh Kennedy dan Eberhart di tahun 1995. Terinspirasi oleh metafora interaksi sosial, algoritma PSO dikembangkan untuk menyimulasikan perilaku sosial kerumunan ikan atau burung, di mana setiap partikel mewakili kandidat solusi dari masalah penelitian [8]. Pang et al. pada tahun mengusulkan algoritma modifikasi dari PSO untuk permasalahan Traveling Salesman Problem (TSP) pada tahun 2004, metode ini dinamakan FPSO [7]. Pada penelitian tersebut, kecepatan dan posisi partikel didefinisikan kembali untuk merepresentasikan relasi fuzzy diantara variabel. Dalam pencarian posisinya yang optimal, nilai velocity (kecepatan) dan posisi partikel harus selalu diperbaiki. Nilai fitness dari setiap posisi partikel diketahui menggunakan fungsi fitness. Nilai kecepatan partikel ditentukan oleh dua nilai posisi terbaik, personal best position (pbest) dan global best position (gbest). Pbest merupakan posisi terbaik dari partikel dan gbest merupakan posisi terbaik dari swarm (kelompok). Algoritma dari FPSO adalah sebagai berikut [7].

1. Berikan nilai awal parameter, termasuk ukuran populasi $P, c_{1}, c_{2}, w$ dan jumlah iterasi terbesar.

2. Buatlah sebuah kelompok dengan $P$ partikel ( $X$, $\mathrm{V}$, pbest, dan gbest pada matriks $n \times c$ ).

3. Berikan nilai awal untuk variabel $X, V$, pbest untuk partikel dan gbest untuk kelompok.

4. Tentukan centroid cluster pada setiap partikel menggunakan Persamaan (1).

5. Tentukan nilai fitness dari setiap partikel menggunakan Persamaan (3).

$$
f(X)=\frac{K}{J_{m}}
$$

6. Tentukan nilai pbest untuk masing-masing partikel.

7. Tentukan nilai gbest untuk masing-masing kelompok.

8. Perbaiki nilai matriks kecepatan untuk masingmasing partikel menggunakan Persamaan (4).

$$
\begin{aligned}
& V(t+1) w \otimes V(t) \oplus\left(c_{1} r_{1}\right) \otimes(\text { pbest }(t) \ominus \\
& X(t)) \oplus\left(c_{2} r_{2}\right) \otimes(g \operatorname{best}(t) \ominus X(t))
\end{aligned}
$$

dengan,

$$
\begin{array}{ll}
V(t) & =\text { kecepatan partikel pada iterasi } t \\
w & =\text { bobot insersia } \\
c_{1}, c_{2} & =\text { koefisien akselerasi } \\
r_{1}, r_{2} & =\text { nilai random antara } 0 \text { dan } 1 \\
X(t) & =\text { posisi partikel pada iterasi } t
\end{array}
$$$$
\operatorname{pbest}(t)=\text { posisi terbaik partikel sampai }
$$
iterasi $t$

$\operatorname{gbest}(t)=$ posisi terbaik kelompok sampai iterasi $t$

9. Perbaiki matriks posisi untuk setiap partikel menggunakan Persamaan (5).

$$
X(t+1)=X(t) \oplus V(t+1)
$$

10. Jika telah mencapai iterasi maksimum atau gbest tidak mengalami penambahan nilai, hentikan algoritma, jika tidak lanjutkan kembali ke langkah empat.

\subsection{Algoritma Hibrid FCM -FPSO}

Algoritma FCM-FPSO adalah algoritma hibrida dari algoritma FCM dan FPSO. Algoritma ini mengatasi kelemahan dari algoritma FCM. Algoritma FCM meski lebih cepat daripada algoritma FPSO karena hanya menggunakan sedikit fungsi evaluasi, namun FCM dapat terperangkap dalam kondisi optimum lokal [7]. Algoritma FCMFPSO mengintegrasikan algoritma FCM dengan algoritma FPSO untuk membentuk suatu algoritma clustering. Algoritma FCM-FPSO mengaplikasikan FCM pada setiap partikel di kelompok untuk setiap iterasi ketika nilai fitness partikel ditingkatkan. Algoritma FCM-FPSO disajikan sebagai berikut [7].

1. Inisialisasi parameter dari FPSO dan FCM (ukuran nilai $P, c_{l}, c_{2}, w$ dan $m$ ).

2. Ciptakan sebuah kelompok dengan partikel $P$ ( $X, V$, pbest, dan gbest pada matriks $n \times \mathrm{x}$ ).

3. Inisialisasi $X, V$, pbest untuk masing-masing partikel dan gbest untuk kelompok.

4. Algoritma FPSO:

a. Tentukan centroid cluster untuk masingmasing partikel menggunakan Persamaan (1).

b. Tentukan nilai fitness dari masing-masing partikel menggunakan Persamaan (3) .

c. Tentukan nilai pbest untuk masing-masing partikel.

d. Tentukan nilai gbest untuk masing-masing kelompok.

e. Perbaiki nilai matriks kecepatan untuk masing-masing partikel menggunakan Persamaan (4). 
f. Perbaiki nilai matriks posisi untuk masingmasing partikel menggunakan Persamaan (5).

g. Jika telah mencapai iterasi maksimum atau gbest tidak mengalami penambahan nilai, hentikan algoritma, jika tidak lanjutkan kembali ke langkah empat.

5. Algoritma FCM:

a. Tentukan centroid cluster untuk masingmasing partikel menggunakan Persamaan (1).

b. Hitunglah jarak Euclidean $d_{i j}, I=1,2, \ldots, n$; $j=1,2, \ldots, c$.

c. Perbarui nilai derajat keanggotaan $\mu_{i j}, i=1$, $2, \ldots, n ; j=1,2, \ldots, c$ untuk masing-masing partikel menggunakan Persamaan 2.

d. Tentukan nilai pbest untuk setiap partikel.

e. Tentukan nilai gbest untuk setiap kelompok.

f. Jika kondisi berhenti algoritma FCM tidak terpenuhi, lanjutkan kembali ke langkah lima.

6. Jika kondisi berhenti FCM-FPSO tidak terpenuhi, lanjutkan kembali ke langkah empat.

2.5 Model Pengembangan Perangkat Lunak metode Unified Process

Unified Process (UP) adalah metode proses pengembangan perangkat lunak yang menyajikan pengembangan perangkat lunak sebagai aktivitas dari empat fase. Keempat fase tersebut terdiri dari tahapan inception (analisis kebutuhan), elaboration (pendefinisian arsitektur), construction (implementasi), dan transition (rilis aplikasi). Pada fase inception dilakukan proses analisis bisnis pada sistem. Fase elaboration dilakukan proses pendefinisian arsitektur sistem. Selanjutnya adalah fase construction, yaitu fase mengimplementasikan sistem, Selanjutnya, fase keempat yaitu transition. Pada fase ini dilakukan proses deploy aplikasi pada lingkungan customer [9].

\section{METODE PENELITIAN}

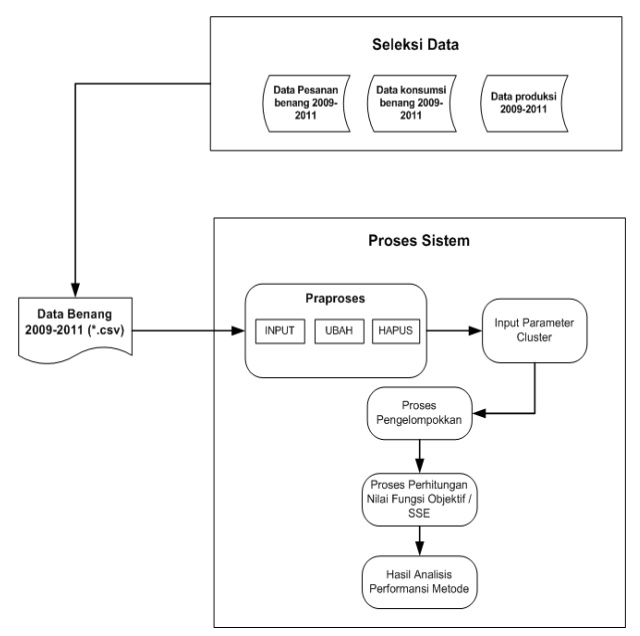

Gambar 1. Tahapan Penelitian
Tahap pertama dilakukan seleksi data, yaitu melakukan proses pemilihan dan penyimpanan data benang yang akan disimpan ke dalam suatu database atau dokumen yang berbeda, dalam hal ini dokumen yang dihasilkan berupa file comma separated values (CSV). File ini berisi data benang dengan atribut id_warna, warna benang, panjang benang, jumlah konsumsi benang, jumlah produk yang menggunakan benang dan jumlah pemesanan benang. Data yang dihimpun merupakan data produksi dan konsumsi benang dari tahun 2009 sampai dengan 2011. Data benang (n) yang dikelompokkan yaitu tahun 2009 sebanyak 96 data, tahun 2010 sebanyak 57 data, tahun 2011 sebanyak 177 data dan data keseluruhan dari tahun 2009 s.d. 2011 sebanyak 209 data. Data berisi field id_benang, warna, panjang, jumlah stok, jumlah konsumsi, dan jumlah pemesanan.

Tahap pra proses merupakan proses pembersihan data benang, mencakup penghapusan duplikasi data, mengecek data benang yang tidak konsisten serta memperbaiki kesalahan data, seperti kesalahan tulis pada atribut data. Pada aplikasi yang dikembangkan ini disediakan beberapa sub proses dari pra proses, yang terdiri dari proses menambah data benang, mengubah data benang dan menghapus data benang. Selanjutnya, tahap transformasi adalah implementasi data ke dalam kode program agar sesuai dengan tahapan data mining yang digunakan. Proses data mining pada penelitian ini adalah tahapan pengimplementasian metode clustering pada kode program. Tahapan terakhir adalah evaluasi, yaitu tahapan mendapatkan knowledge yang dihasilkan dari proses data mining.

\section{HASIL DAN PEMBAHASAN}

Pengembangan aplikasi pengelompokkan data benang (PPDB) menngadaptasi metode unified process. Pada fase inception dilakukan analisis kebutuhan bisnis dari sistem. Kebutuhan fungsional dari aplikasi PPDB ini dapat dilihat pada Gambar 2.

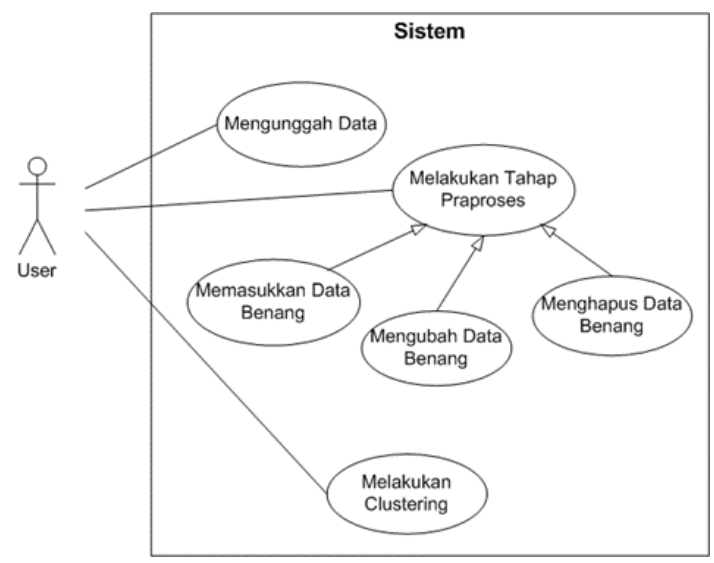

Gambar 3. Diagram Use case Aplikasi PPDB 
Terdapat enam use case yang didefinisikan pada aplikasi PPDB. Use case tersebut yaitu, menggunggah data, melakukan tahap praproses, memasukkan atau menambah data, mengubah data, menghapus data, serta melakukan clustering. Use case memasukkan, mengubah, dan menghapus data merupakan generalisasi dari use case melakukan tahapan praproses.

Pada fase elaboration, didefinisikan arsitektur dari sistem berupa kelas diagram. Terdapat 14 kelas yang digunakan oleh aplikasi PPDB. Deskripsi dari keempat belas tersebut disajikan pada Tabel 1.

Tabel 2. Deskripsi Kelas Aplikasi PPDB

\begin{tabular}{|c|c|c|c|}
\hline $\begin{array}{l}\mathbf{N} \\
\mathbf{O}\end{array}$ & $\begin{array}{c}\text { Nama } \\
\text { Kelas }\end{array}$ & $\begin{array}{c}\text { Tipe } \\
\text { Kelas } \\
\end{array}$ & Deskripsi \\
\hline 1 & V_main & $\begin{array}{l}\text { Boundar } \\
y\end{array}$ & $\begin{array}{l}\text { Kelas ini berfungsi untuk } \\
\text { menghubungkan pengguna } \\
\text { dengan form praproses dan } \\
\text { clustering. Kelas ini juga } \\
\text { digunakan untuk proses } \\
\text { mengunggah data. }\end{array}$ \\
\hline 2 & C_unggah & Control & $\begin{array}{l}\text { Kelas ini berisi method } \\
\text { untuk menampilkan form } \\
\text { praproses dan clustering. } \\
\text { Kelas ini juga berisi } \\
\text { method untuk mengunggah } \\
\text { data }\end{array}$ \\
\hline 3 & $\begin{array}{l}\text { V_praprose } \\
\mathrm{s}\end{array}$ & $\begin{array}{l}\text { Boundar } \\
y\end{array}$ & $\begin{array}{lr}\text { Kelas ini } & \text { merupakan } \\
\text { antarmuka } & \text { yang } \\
\text { menampilkan tabel } & \text { data } \\
\text { benang. Kelas } & \text { ini } \\
\text { berhubungan } & \text { dengan } \\
\text { C_praproses } & \text { dan } \\
\text { TabelBenang. } & \\
\end{array}$ \\
\hline 4 & $\begin{array}{l}\text { C_praprose } \\
\mathrm{s}\end{array}$ & Control & $\begin{array}{l}\text { Kelas ini berisi method } \\
\text { untuk mengolah data } \\
\text { benang pada tabel benang. } \\
\text { Method tersebut yaitu } \\
\text { insert, ubah dan hapus. }\end{array}$ \\
\hline 5 & Benang & Entity & $\begin{array}{l}\text { Kelas ini berisi setter dan } \\
\text { getter terhadap data } \\
\text { benang (id, warna, } \\
\text { panjang, konsumsi, produk } \\
\text { dan pesanan) }\end{array}$ \\
\hline 6 & $\begin{array}{l}\text { TabelBenan } \\
\mathrm{g}\end{array}$ & Control & $\begin{array}{l}\text { Kelas ini berisi method } \\
\text { untuk menampilkan data } \\
\text { benang ke dalam tabel pada } \\
\text { interface V_praproses. }\end{array}$ \\
\hline 7 & V_cluster & $\begin{array}{l}\text { Boundar } \\
y\end{array}$ & $\begin{array}{lr}\text { Merupakan antarmuka } \\
\text { yang menerima } & \text { inputan } \\
\text { parameter } & \text { dan } \\
\text { menampilkan } & \text { hasil } \\
\text { clustering. } & \\
\end{array}$ \\
\hline 8 & C_cluster & Control & $\begin{array}{l}\text { Kelas ini berisi method } \\
\text { untuk mengelompokkan } \\
\text { data dan perhitungan nilai } \\
\text { best, avg dan worst setiap } \\
\text { metode. }\end{array}$ \\
\hline 9 & Cluster & Entity & $\begin{array}{l}\text { Kelas ini berisi setter dan } \\
\text { getter terhadap data cluster }\end{array}$ \\
\hline 10 & $\begin{array}{l}\text { TabelCluste } \\
r\end{array}$ & Control & $\begin{array}{l}\text { Kelas ini berisi method } \\
\text { untuk menampilkan data } \\
\text { cluster ke dalam bentuk } \\
\text { tabel pada interface } \\
\text { V_cluster. }\end{array}$ \\
\hline 11 & FCM & Control & $\begin{array}{l}\text { Merupakan kelas yang } \\
\text { berisi atribut dan method } \\
\text { pengelompokan yang }\end{array}$ \\
\hline
\end{tabular}

\begin{tabular}{|c|c|c|c|}
\hline $\begin{array}{l}\mathbf{N} \\
\mathbf{O}\end{array}$ & $\begin{array}{l}\text { Nama } \\
\text { Kelas }\end{array}$ & $\begin{array}{l}\text { Tipe } \\
\text { Kelas }\end{array}$ & Deskripsi \\
\hline & & & $\begin{array}{l}\text { digunakan pada algoritma } \\
\text { FCM. }\end{array}$ \\
\hline 12 & FPSO & Control & $\begin{array}{lrr}\text { Merupakan kelas yang } \\
\text { berisi atribut dan method } \\
\text { pengelompokan yang } \\
\text { digunakan pada algoritma } \\
\text { FPSO. Kelas r ini } \\
\text { merupakan turunan dari } \\
\text { kelas FCM }\end{array}$ \\
\hline 13 & FCMFPSO & Control & $\begin{array}{l}\text { Merupakan kelas yang } \\
\text { berisi atribut dan method } \\
\text { pengelompokan yang } \\
\text { digunakan pada algoritma } \\
\text { FCM-FPSO. Kelas ini } \\
\text { merupakan turunan dari } \\
\text { kelas FPSO }\end{array}$ \\
\hline 14 & Parameter & Entity & $\begin{array}{l}\text { Kelas ini berisi nilai } \\
\text { parameter yang merupakan } \\
\text { inputan dari forn } \\
\text { V_Cluster. }\end{array}$ \\
\hline
\end{tabular}

Selanjutnya adalah fase construction. Implementasi sistem dilakukan menggunakan bahasa pemograman Java. Tampilan awal dari aplikasi PPDB dapat dilihat pada Gambar 4. Pada halaman awal, user dapat menggenerate file *.csv untuk mengimpor data di file ke dalam aplikasi.

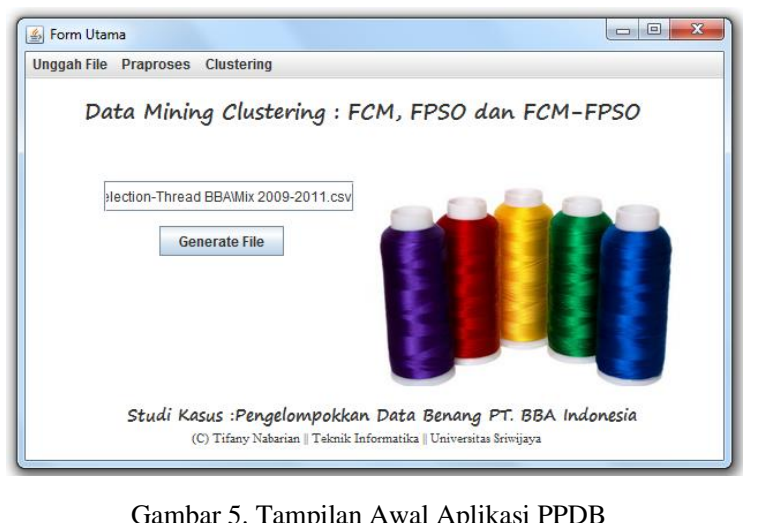

Data yang diimpor kemudian ditampilkan pada form praproses yang disajikan pada Gambar 6.

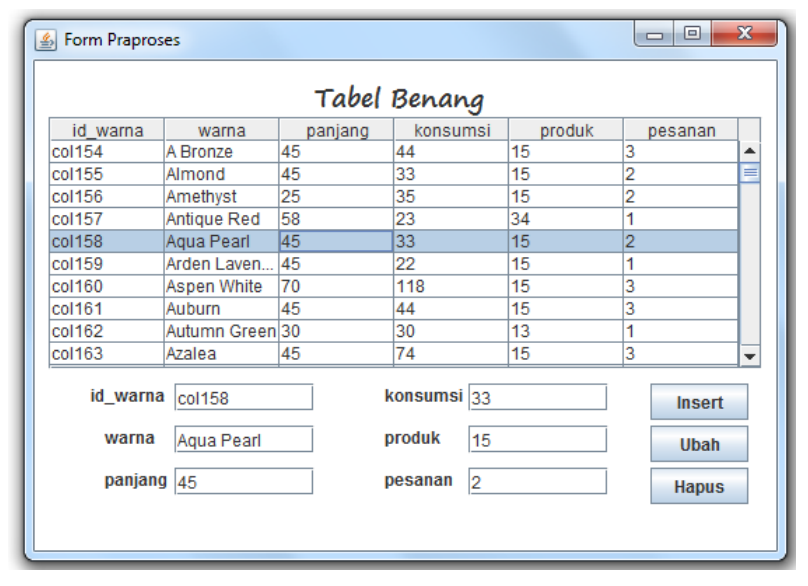

Gambar 7. Form Praproses pada Aplikasi PPDB 
Tampilan selanjutnya adalah form clustering yang disajikan pada Gambar 8. Pada proses input parameter, nilai awal yang perlu dimasukkan pada sistem adalah jumlah cluster (c), nilai bobot fuzzy (m), dengan syarat nilai $\mathrm{c}$ dan $\mathrm{m}$ harus lebih besar dari satu (c $>1$ dan $m>1$ ) dan jumlah iterasi maksimum berlangsungnya proses pengelompokkan (t). Ketiga nilai tersebut perlu diinisialisasi oleh pengguna karena merupakan parameter yang berpengaruh pada setiap algoritma yang digunakan. Nilai random dan koefisien akselerasi ditentukan oleh sistem, begitu juga untuk inisialisasi matriksmatriks parameter lainnya. Sementara itu, untuk dimensi matriks ditentukan oleh banyaknya baris data benang (n) dan kolom jumlah cluster yang dibentuk (c).

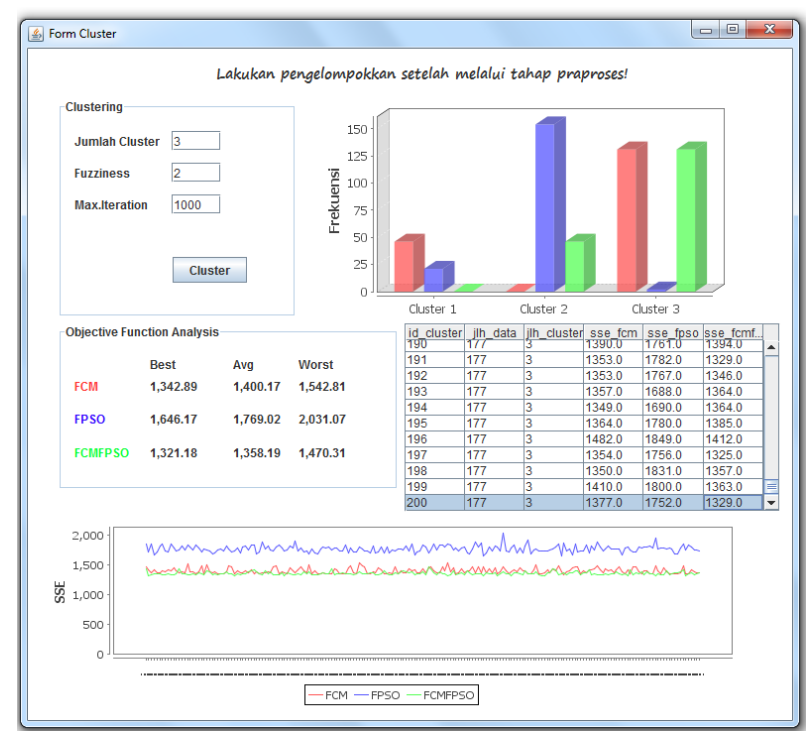

Gambar 9. Form Clustering

Enam kebutuhan fungsional yang digambarkan pada diagram use case diuji berdasarkan skenario pengujian metode black-box. Skenario terdiri dari input dan output yang diharapkan pada sistem. Tabel 3. menyajikan skenario pengujian untuk kebutuhan fungsional "Melakukan Clustering". Hasil pengujian menunjukkan bahwa semua skenario yang diuji menghasilkan keluaran yang sesuai dengan harapan.

Tabel 4. Skenario Pengujian Use Case Melakukan Clustering

\begin{tabular}{llll}
\hline ID & \multicolumn{1}{c}{ Prosedur Input } & Output & Kesimpulan \\
\hline $\mathbf{U}-$ & Memilih Menu & $\begin{array}{l}\text { Tampilan } \\
\text { form }\end{array}$ & Diterima \\
$\mathbf{3 -}$ & $\begin{array}{l}\text { Clustering -> } \\
\text { 101 }\end{array}$ & $\begin{array}{l}\text { Menekan menu } \\
\text { Clustering }\end{array}$ & \\
& Clustering & \\
\hline $\mathbf{U}-$ & Mengisi inisialisasi & Notifikasi & Diterima \\
$\mathbf{3 -}$ & parameter dengan & kesalahan & \\
$\mathbf{1 0 2}$ & $\begin{array}{l}\text { huruf “a" -> Menekan } \\
\text { input }\end{array}$ & \\
& menu Clustering & & \\
\hline $\mathbf{U}-$ & $\begin{array}{l}\text { Mengisi jumlah } \\
\text { 3- }\end{array}$ & $\begin{array}{l}\text { Notifikasi } \\
\text { kesalahan }\end{array}$ & Diterima \\
$\mathbf{1 0 3}$ & dengan nilai <2 -> & input & \\
& Menekan menu & & \\
& Clustering & & \\
\hline
\end{tabular}

\begin{tabular}{llll}
\hline U- & Melakukan & Hasil & Diterima \\
3- & pengelompokkan -> & cluster & \\
$\mathbf{1 0 4}$ & Menekan menu & disimpan \& & \\
& Clustering & grafik & \\
& & ditampilkan & \\
\end{tabular}

Pengelompokkan data benang pada aplikasi PPDB dilakukan sebanyak 200 kali untuk setiap data benang (pertahun dan keseluruhan). Jumlah cluster (c) yaitu sebanyak 3 cluster untuk tahun 2011 dan data keseluruhan, dan sebanyak 5 cluster untuk tahun 2009 dan 2010. Nilai fuzziness $\mathrm{m}=2$, nilai random $(\mathrm{r} 1, \mathrm{r} 2)$ dalam rentang $[0,1]$, nilai koefisien akselerasi (c1, c2) adalah 2 dan nilai bobot inersia (w) dalam rentang $[0,9,0,1]$. Hasil perhitungan nilai fungsi objektif pada setiap metode disajikan pada Tabel 5.

Tabel 6. Hasil Clustering Data Benang

\begin{tabular}{|c|c|c|c|c|c|}
\hline \multicolumn{2}{|c|}{ Data Benang $(n, c)$} & \multirow{2}{*}{$\begin{array}{c}\begin{array}{c}2009 \\
(96, \\
\mathbf{5})\end{array} \\
385,1 \\
5 \\
\end{array}$} & \multirow{2}{*}{$\begin{array}{l}\mathbf{2 0 1 0} \\
(\mathbf{5 7}, \\
\mathbf{5}) \\
278,5 \\
6\end{array}$} & \multirow{2}{*}{$\begin{array}{l}\begin{array}{c}\mathbf{2 0 1 1} \\
(\mathbf{1 7 7}, \\
\mathbf{3})\end{array} \\
1342,8 \\
9\end{array}$} & \multirow{2}{*}{\begin{tabular}{l}
\multicolumn{1}{c}{ Mix } \\
$(\mathbf{2 0 9}$, \\
3) \\
3413,4 \\
4
\end{tabular}} \\
\hline FCM & Worst & & & & \\
\hline & $\begin{array}{l}\text { Averag } \\
e\end{array}$ & $\begin{array}{l}348,1 \\
8\end{array}$ & $\begin{array}{l}293,2 \\
2\end{array}$ & $\begin{array}{l}1400,1 \\
7\end{array}$ & $\begin{array}{l}3540,3 \\
3\end{array}$ \\
\hline & Best & $\begin{array}{l}323,6 \\
2\end{array}$ & $\begin{array}{l}322,3 \\
2\end{array}$ & $\begin{array}{l}1542,8 \\
1\end{array}$ & 3801,4 \\
\hline \multirow[t]{3}{*}{ FPSO } & Worst & $\begin{array}{l}490,9 \\
6\end{array}$ & $\begin{array}{l}378,2 \\
4\end{array}$ & $\begin{array}{l}1646,1 \\
7\end{array}$ & $\begin{array}{l}4213,1 \\
5\end{array}$ \\
\hline & $\begin{array}{l}\text { Averag } \\
e\end{array}$ & $\begin{array}{l}517,9 \\
8 \\
\end{array}$ & $\begin{array}{l}408,6 \\
1\end{array}$ & $\begin{array}{l}1769,0 \\
2\end{array}$ & 4485,4 \\
\hline & Best & $\begin{array}{l}561,6 \\
6\end{array}$ & 450 & $\begin{array}{l}2031,0 \\
7\end{array}$ & $\begin{array}{l}4991,5 \\
6\end{array}$ \\
\hline \multirow[t]{3}{*}{$\begin{array}{l}\text { FCMFPS } \\
\mathrm{O}\end{array}$} & Worst & $\begin{array}{l}374,7 \\
5\end{array}$ & $\begin{array}{l}250,5 \\
2\end{array}$ & $\begin{array}{l}1321,1 \\
8\end{array}$ & $\begin{array}{l}3326,7 \\
6\end{array}$ \\
\hline & $\begin{array}{l}\text { Averag } \\
e\end{array}$ & $\begin{array}{l}345,1 \\
7\end{array}$ & $\begin{array}{l}282,6 \\
2\end{array}$ & $\begin{array}{l}1358,1 \\
9\end{array}$ & 3441 \\
\hline & Best & $\begin{array}{l}319,8 \\
5\end{array}$ & $\begin{array}{l}315,0 \\
7\end{array}$ & $\begin{array}{l}1470,3 \\
1\end{array}$ & $\begin{array}{l}3657,6 \\
4\end{array}$ \\
\hline
\end{tabular}

Tabel 7. menunjukkan metode FCM-FPSO menghasilkan nilai fungsi objektif paling minimum atau terkecil dari kedua metode lainnya. Nilai ratarata fungsi objektif terendah dicapai oleh algoritma hibrid FCM-FPSO sebesar 3441,00 kemudian diikuti oleh algoritma FCM dengan nilai sebesar 3540,33 dan yang tertinggi dicapai oleh algoritma FPSO dengan nilai sebesar 4485,40. Semakin kecil nilai fungsi objektif yang dihasilkan maka semakin baik cluster yang terbentuk [7]. Hal ini menunjukkan cluster yang dihasilkan oleh metode FCM-FPSO adalah yang terbaik dibandingkan kedua metode lainnya yang telah diuji.

\section{KESIMPULAN}

Penelitian ini menguji performansi metode hibrid FCM-FPSO dengan mengimplementasikannya ke sebuah aplikasi pengelompokan data benang pada perusahaan tekstil. Metode dengan nilai performa terbaik untuk pengelompokan data benang, yaitu metode hibrid FCM-FPSO, dengan nilai rata-rata fungsi objektif terendah mencapai angka 3441,00, paling kecil di antara dua algoritma lainnya. Hal ini menunjukkan bahwa aplikasi yang dikembangkan 
berhasil menguji performa metode FCM-FPSO. Hasil cluster metode FCM-FPSO yang didapatkan dari aplikasi PPDB menjadi rekomendasi untuk perusahaan tekstil untuk menyusun strategi pembelian benang untuk periode yang akan datang.

\section{DAFTAR PUSTAKA}

[1] K. Mehmed, Data Mining: Concepts, Models, Methods, and Algorithms, 3rd ed. Hoes Lane: IEEE Press \& Wiley, 2020.

[2] R. Rustiyan and M. Mustakim, "Penerapan Algoritma Fuzzy C Means untuk Analisis Permasalahan Simpanan Wajib Anggota Koperasi," J. Teknol. Inf. dan Ilmu Komput., vol. 5, no. 2, p. 171, 2018.

[3] S. Rani, A. Puspita, and F. Nhita, "Implementasi Algoritma Fuzzy C-Means untuk Mengkategorikan Tingkat Penjualan Produk pada Data Transaksi Swalayan," e-Proceeding Eng., vol. 5, no. 3, pp. 8206-8217, 2018.

[4] F. Agustini, "Implementasi Algoritma Fuzzy C-Means Studi Kasus Penjualan di Sushigroove Restaurant," JITK (Jurnal Ilmu Pengetah. dan Teknol. Komputer), vol. 3, no. 1, pp. 127-132, 2019.

[5] T. M. Silva Filho, B. A. Pimentel, R. M. C. R. Souza, and A. L. I. Oliveira, "Hybrid methods for fuzzy clustering based on fuzzy c-means and improved particle swarm optimization," Expert Syst. Appl., vol. 42, no. 17-18, pp. 6315-6328, 2015.

[6] C. Skiadas and J. Bozeman, Data Analysis and Applications 1, 2nd ed. Wiley, 2019.

[7] H. Izakian and A. Abraham, "Fuzzy Cmeans and fuzzy swarm for fuzzy clustering problem," Expert Syst. Appl., vol. 38, no. 3, pp. 1835-1838, 2011.

[8] W. Liu, Z. Wang, X. Liu, N. Zeng, and D. Bell, "A Novel Particle Swarm Optimization Approach for Patient Clustering from Emergency Departments," IEEE Trans. Evol. Comput., vol. 23, no. 4, pp. 632-644, 2019.

[9] I. Sommerville, Software EngineeringSommerville(Tenth Edition), 10th ed. Pearson Education, 2016. 